\title{
ELECTROPHORETIC ISOLATION OF A CIRCULATING ANTICOAGULANT
}

\author{
By F. L. MUNRO AND MURIEL PLATT MUNRO \\ (From the Charlotte Drake Cardeza Foundation, Department of Medicine, \\ Jefferson Medical College and Hospital, Philadelphia)
}

(Received for publication May 20, 1946)

We recently reported (1) on the properties of a circulating anticoagulant found in the blood of a hemophiliac. At that time it was shown that the anticoagulant activity was associated with the globulin fractions of the plasma. In this paper we wish to report on the electrophoretic fractionation of plasma from this patient, and to present data indicating that the anticoagulant activity is associated with the $\gamma$ globulin.

\section{METHODS AND MATERIAL}

The plasma used in these studies was obtained in one bleeding collected into one-ninth of its volume of $0.1 \mathrm{M}$ sodium oxalate. The blood was then centrifuged and the plasma stored at $-20^{\circ} \mathrm{C}$. until used. There was no decrease in the anticoagulant activity under these conditions.

The electrophoretic fractionations were carried out in a large cell, with a capacity of $100 \mathrm{ml}$., similar to that employed by Blix, Tiselius and Svensson (2), consisting of 4 center sections each $46 \mathrm{~mm}$. high with a cross-section of $50 \times 7.5 \mathrm{~mm}$. Since the fractions obtained were to be tested for their anticoagulant activity, a barbiturate buffer of $\mathrm{pH} 7.5$ was employed. The buffer contained $0.01 \mathrm{M}$ sodium diethylbarbiturate, $0.006 \mathrm{M}$ hydrochloric acid and $0.15 \mathrm{M}$ sodium chloride. The undiluted plasma was dialyzed in $18 / 32$ inch Visking tubing for 24 hours against 2 changes of $1,000 \mathrm{ml}$. of buffer, and for 24 hours against $2,000 \mathrm{ml}$. of the buffer. As suggested by Tiselius (3) the lower half of each electrode vessel was filled with a buffer having 4 times the concentration of the buffer against which the plasma was dialyzed. The remainder of the electrode vessels and the cell were filled with the buffer employed for the final dialysis. Electrophoresis was carried out for 67 hours at $1^{\circ} \mathrm{C}$. with a constant potential gradient of approximately 1.5 volts per $\mathrm{cm}$.

The separated fractions were removed through a long capillary tube attached to a $50 \mathrm{ml}$. syringe. The material was withdrawn at a constant rate of approximately 0.5 ml. per minute. This was done by attaching the plunger of the syringe to a screw drive, which was driven by a synchronous motor through a suitable gear train. The tip of the capillary was lowered to the desired position by means of a screw moved by 2 spiral gears. Under schlieren observation 2 fractions were removed from each side; namely, (1) ascending albumin plus $\alpha$ globulin, (2) ascending albumin plus $\alpha$ and $\beta$ globulins, (3) descending $\gamma$ globulin plus fibrinogen, and (4) descending $\gamma$ and $\beta$ globulins plus fibrinogen.
The fractions were tested for their anticoagulant activity by determining the extent to which they would prolong the coagulation time of recalcified normal plasma. Previous studies (1) have shown that $0.2 \mathrm{ml}$. of the plasma containing the anticoagulant will markedly prolong the coagulation time of $0.4 \mathrm{ml}$. of normal plasma. In testing the fractions obtained by electrophoresis a similar procedure was used.

No attempt was made to remove the buffer by dialysis before testing the samples, since it was found that the buffer used in this study did not affect the coagulation time of recalcified normal plasma to any greater extent than an equal volume of $0.15 \mathrm{M}$ sodium chloride.

Besides the various fractions, the unfractionated material remaining in the bottom section of the cell was tested. This gave an indication of whether any changes had occurred in the anticoagulant activity during electrophoresis.

The protein content of the fractions was determined by digesting a suitable aliquot with sulfuric acid and superoxol followed by Nesslerization. The color developed was read in the Evelyn colorimeter. A correction was applied to the nitrogen values so obtained for the nitrogen contained in the buffer, following which the protein was calculated by multiplying by the factor 6.25 .

\section{RESULTS}

The data obtained in this study are shown in Tables I and II. From Table I, showing the results of tests made on fractions obtained by electrophoresis in the large cell, it can be seen that only the fractions containing $\gamma$ globulin displayed anticoagulant activity. Both the $\gamma$ globulin plus fibrinogen fraction and the $\gamma$ and $\beta$ globulins plus fibrinogen fraction showed anticoagulant activity.

TABLE I

Fractionation of whole plasma

Fraction added to normal plasma Coagulation time* min.

Plasma after dialysis

Albumin plus $\alpha$ globulin

Albumin plus $\alpha$ and $\beta$ globulins

$\gamma$ globulin plus fibrinogen

$\gamma$ and $\beta$ globulins plus fibrinogen

Plasma from bottom section of cell

Buffer

* Each test was made using $0.2 \mathrm{ml}$. of the fraction, 0.4 $\mathrm{ml}$. of normal plasma, and $0.4 \mathrm{ml}$. of $0.025 \mathrm{M}$ calcium chloride. 
TABLE II

Separation of $\gamma$ and $\beta$ globulin

\begin{tabular}{l|c|c}
\hline \hline \multicolumn{1}{|c|}{ Fraction added to normal plasma } & $\begin{array}{c}\text { Coagu- } \\
\text { lation } \\
\text { time* }\end{array}$ & Protein \\
\hline & $\operatorname{min.}$ & $\begin{array}{c}\text { grams per } \\
100 \mathrm{ml} .\end{array}$ \\
$\gamma$ and $\beta$ globulins after dialysis & 34 & 0.85 \\
$\beta$ globulin & 4 & 0.25 \\
$\gamma$ globulin & 24 & 0.39 \\
Material from bottom section of cell & 23 & \\
Buffer & 3 & \\
\hline
\end{tabular}

* Each test was made using $0.2 \mathrm{ml}$. of the fraction, 0.4 $\mathrm{ml}$. of normal plasma, and $0.4 \mathrm{ml}$. of $0.025 \mathrm{M}$ calcium chloride.

The 2 fractions, albumin plus a globulin, and albumin plus $a$ and $\beta$ globulins, failed to show any anticoagulant activity.

The 2 fractions, $\gamma$ globulin plus fibrinogen and $\gamma$ and $\beta$ globulins plus fibrinogen, obtained in the large cell fractionation, were mixed and the fibrinogen converted to fibrin by the addition of $1 / 20$ volume of thrombin. The solution remaining after removal of the fibrin presumably contained only $\gamma$ and $\beta$ globulins.

This solution was fractionated in the $11 \mathrm{ml}$. divided cell (4) in such a manner that the upper half of the descending side contained $\gamma$ globulin, and the upper half of the ascending side contained $\beta$ globulin. Tests on these fractions (Table II) confirmed the observation previously made, that the anticoagulant under investigation migrates as a $\gamma$ globulin.

\section{SUMMARY}

Plasma from a hemophiliac, containing an anomalous anticoagulant, has been fractionated by electrophoresis. Tests on the various fractions show that the anticoagulant activity is associated with the $\gamma$ globulin fraction.

We wish to acknowledge the technical assistance of Miss Annabel Avery, B.A.

\section{BIBLIOGRAPHY}

1. Munro, F. L., Properties of an anticoagulant found in the blood of a hemophiliac. J. Clin. Invest., $1946,25,422$.

2. Blix, G., Tiselius, A., and Svensson, H., Lipids and polysaccharides in electrophoretically separated blood serum proteins. J. Biol. Chem., 1941, 137, 485.

3. Tiselius, A., Some aspects of the purification and characterization of high molecular substances. Svensk. Kem. Tid., 1938, 50, 58.

4. Tiselius, A., A new apparatus for electrophoretic analysis of colloidal mixtures. Trans. Faraday Soc., 1937, 33, 524. 